DOI: $10.17805 /$ zpu.2017.2.13

\title{
«Ромео и Джульетта» Шекспира в критике и поэтике А. С. Пушкина
}

\author{
H. B. ЗАХАРОB
}

МОСКОВСКИЙ ГУМАНИТАРНЫЙ УНИВЕРСИТЕТ

Принято считать, что трагедия У. Шекспира «Ромео и Джульетта» не оставила в творчестве А. С. Пушкина значительного следа. Обычно отмечают сходство в интерпретации любовного сюжета и образов лирических героев, конфликт между враждующими семьями родителей и т. д. Большое значение в изучении шекспиризации и шекспиризма в русской литературе имеет тезаурусный подход (В. А. Луков, Вл. А. Луков), который применяет автор статьи для анализа творчества Пушкина. В статье уточняется, какое место печальная история юных возлюбленных играла в творческом развитии русского поэта.

Начиная с 1770-1780-х годов в русской литературе стал набирать силу процесс шекспиризации. В журналах публикуются попытки перевода отдельных отрывков из шекспировских пьес. Романтический культ Шекспира в России начала XIX в. был целиком подготовлен предромантическим влиянием европейской литературы XVIII в. А. С. Пушкин, а также 
В. К. Кюхельбекер, А. С. Грибоедов, О. М. Сомов, опирались на пример Шекспира и создавали самобытную национальную литературу, пропитанную духом народности. Пушкин был несомненно наиболее значительным русским шекспиристом. Это прослеживается в его творческой эволюции.

Шекспир и его герои, в первую очередь Ромео и Джульетта, постоянно упоминаются в рукописях Пушкина. Их литературно-критический уровень настолько значителен и самоценен, что исследователи предполагали, что поэт собирался написать «трактат о Шекспире». После «Бориса Годунова» и «Графа Нулина» пушкинский шекспиризм приобрел более отчетливые черты. Шекспировские аллюзии заметны и в поэтических произведениях, и в драматургии Пушкина.

Во второй половине XIX - начале XX в. русская культура продолжала развивать пушкинскую модель шекспиризма в творчестве русских писателей (Ф. М. Достоевский, И. С. Тургенев, А. П. Чехов, А. А. Блок, Б. Л. Пастернак и др.). Значительными оказались музыкальные произведения: вдохновленные шекспировской пьесой увертюра-фантазия «Ромео и Джульетта» П. И. Чайковского и признанный классический балет С. С. Прокофьева. В живописи заметными явлениями стали работы М. А. Врубеля, М. З. Шагала и др. Новаторский характер имели в 1920-1930-х годах театральные постановки пьесы Шекспира. Таким образом, к середине XX в. трагедия Шекспира прочно вошла в русскую культуру. Ключевые слова: А. С. Пушкин; У. Шекспир; «Ромео и Джульетта»; литературная критика; литературная поэтика; тезаурусный подход; шекспиризм; русская литература

\section{BВЕАЕНИЕ}

П ринято считать, что трагедия У. Шекспира «Ромео и Ажульетта» не оставила 1 в творчестве А. С. Пушкина такого значительного следа, как, например, шекспировские исторические хроники, пьеса «Мера за меру» или даже его кровавая поэма «Обесчещенная Аукреция». Обычно отмечают сходство в интерпретации любовного сюжета и образов лирических героев, конфликт между враждующими семьями родителей и т. А. (см.: Узин, 1924; Алексеев, 1972, 1982, 1987; Аевин, 1974, 1988; Купреянова, 1981; Петрунина, 1987; Просцевичус, 1998; Эйхенбаум, 2001; Аолинин, 2001, 2007). Сравнительно недавно М. В. Елифёрова выявила особую роль пьесы «Ромео и Ажульетта» в ранней рецепции Шекспира в России и ее влияние на «Повести Белкина» (Елифёрова, 2007; см. также более ранние работы: Елифёрова, 2003, 2005 и др.). Важное значение в изучении шекспиризации и шекспиризма в русской литературе имеет тезаурусный анализ (см.: I Академические чтения ..., 2015). Его принципы и методика раскрыты в работах Вал. А. и Вл. А. Ауковых (Ауков В., Ауков Вл., 2008, 2013). Свой вклад в развитие этой методологии внесли И. В. Вершинин (Вершинин, 2003), С. Н. Есин (Есин, 2006), Т. Ф. Кузнецова, (Кузнецова, 2012, 2015: Электронный ресурс; Кузнецова, Ауков, 2009), Н. В. Соломатина (Соломатина, 2003), А. Б. Тарасов (Тарасов, 2006), В. П. Трыков (Трыков, 2016), Ч. К. Аамажаа (Аамажаа, 2012), Б. Н. Гайдин (Гайдин, 2009), Э. К. Погорский (Погорский, 2012) и др.

Попытаемся уточнить, какое место печальная история юных возлюбленных играла в творческом развитии русского поэта.

\section{ИСТОРИЯ ВОПРОСА}

Начиная с 1770-1780-х годов в русской литературе стал набирать силу процесс шекспиризации. В журналах публикуются робкие попытки перевода отдельных отрывков из шекспировских пьес. В 1772 г. появился перевод «Монолога Ромео» из 3-й сцены V действия, выполненный М. В. Сушковой (Шекспир, 1772).

Еще две русские обработки пьесы появились в конце XVIII - начале XIX в. и бы-

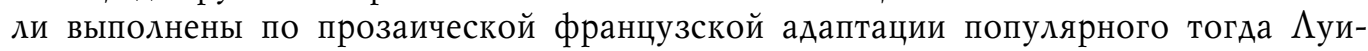


Себастьяна Мерсье (Les Tombeaux de Vérone, 1782). Пьеса «Ромео и Юлия, драма в пяти действиях» талантливого актера В. П. Померанцева (1790) и трехактная мелодрама А. Г. Ротчева (1825-1827) имели благополучный финал. Ротчев был хорошо известен в дружеском кругу Пушкина. По мнению П. Р. Заборова, «во второй половине 1820-х годов подобное сочинение, естественно, не могло уже вызвать особого восторга» (Заборов, 1965: 70). Сравним, например, мнения современников: «...Аетский сколок с весьма известной шекспировой трагедии и столько же известной французской оперы на русском языке» (Аамский журнал, 1827: 177). Под оперой имелась в виду русскоязычная версия «Ромео и Юлии» немецкого пианиста А. Г. Штейбельта (Daniel Gottlieb Steibelt, 1765-1823), который сочинил оперу под названием Roméo et Juliette. Ее премьера состоялась в парижском театре Théâtre Feydeau в 1793 г. Большинство критиков, включая Г. Берлиоза, считали ее лучшим из всего оригинального творчества композитора. По личному приглашению Александра I он прибыл в Санкт-Петербург, где возглавил Императорский театр оперы и балета (см.: Гозенпуд, 1959: 433-434). Его «Ромео и Юлия» с огромным успехом ставилась в обеих столицах в 1809 г. В том же году появился балет известного русского хореографа и танцовщика Ивана Вальберха (см.: Вальберх, 1948: 19-20, 173). К. А. Полевой окрестил творение Ротчева «преуродливым», «незрелым произведением юноши, скропанным для бенефиса» (Полевой, 1888: 145).

Анонимный перевод «Ромео и Ажульетты» был выполнен в прозе в 1828 г., и хотя он был значительно ближе к трагедии Шекспира, но восходил к немецкому переводу Шлегеля и Тика, а не к оригиналу (см.: Северная пчела, 1829), рукопись этого перевода хранится в Государственной театральной библиотеке (I.VII.3.3). Несколько фрагментов шекспировской трагедии с подлинника перевел П. А. Плетнев, который опубликовал их в 1828-1829 гг. в «Северных цветах» (Вацуро, 2004: 220). Хотя в Малом театре в Москве П.С. Мочалов блистал в роли Ромео уже в 1824 г., успешная театральная судьба трагедии сложилась уже после гибели поэта.

Романтический культ Шекспира в России начала XIX в. был целиком подготовлен предромантическим влиянием европейской литературы XVIII в. (см., напр.: Ауков, 2006). Такие русские писатели, как А. С. Пушкин, В. К. Кюхельбекер, А. С. Грибоедов, О. М. Сомов, опирались на пример Шекспира и создавали самобытную национальную литературу, пропитанную духом народности (Ауков, Захаров, 2008; Ауков, 2011). Несомненно, наиболее значительным русским шекспиристом был А. С. Пушкин. Активный интерес к творчеству Шекспира проявился и в общении Пушкина со своими друзьями и коллегами. Подтверждения этому находятся в многочисленных бумагах, письмах поэта, в его книжном собрании. Вслед за декабристами Пушкин ставит задачу создания русской национальной литературы, в чем преуспел больше всех остальных.

Шекспир и его герои постоянно упоминаются в рукописях русских писателей, по ним можно проследить не только развитие интереса к творчеству британского драматурга, но и саму творческую эволюцию русского поэта (см. рукописи за 1826-1836 гг.: «О народности в литературе» 1826 г.; материалы к «Отрывкам из писем, мыслям и замечаниям» 1827 г.; «В зрелой словесности приходит время» 1828 г.; набросок «О романах В. Скотта» 1829-1830 гг.; набросок плана статьи «О народной драме и драме "Марфа Посадница"» 1830 г.; заметку Пушкина, опубликованную без его подписи

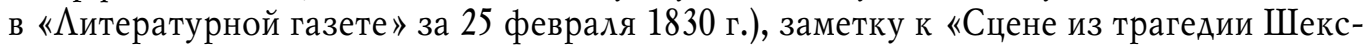
пира "Ромео и Юлия" в переводе П. А. Плетнева», многочисленные письма к друзьям, 
полемику с критиками по поводу поэмы «Полтава», отрывок о Шейлоке, Анджело и Фальстафе, относящийся к серии заметок, объединенных заглавием Table-talk). Их литературно-критический уровень настолько значителен и самоценен, что исследователи предполагали, что поэт собирался написать «трактат о Шекспире».

После «Бориса Годунова» и «Графа Нулина» пушкинский шекспиризм приобрел более отчетливые черты: «Прилежное, вдумчивое изучение Шекспира, относящееся к годам ссылки Пушкина в Михайловское, продолжалось и в последующие годы, не ослабевая, а скорее усиливаясь с течением времени. Плоды своих размышлений над текстами Шекспира Пушкин иногда набрасывал и на бумагу; кое-что из таких рукописей им самим направлено было в печать, другие сохранились среди его бумаг и увидели свет только после его смерти» (Алексеев, 1972: 259-260). Например, известна одна сравнительно небольшая пушкинская заметка, которая без его подписи была напечатана в примечании к «Сцене из трагедии Шекспира: Ромео и Юлия» в переводе П. А. Плетнева в альманахе «Северные цветы за 1830 г.» (СПб., 1829). Посвященная пьесе великого английского драматурга заметка «обнаруживает несомненную осведомленность его в специальной литературе об английском театре» (там же: 260). Например, Пушкин знал о дискуссиях, возникших вокруг вопроса об авторстве пьес Шекспира, шедших в то время в западноевропейской критической и научной литературе: «Многие из трагедий, приписываемых Шекспиру, ему не принадлежат, а только им поправлены. Трагедия Ромео и Ажюльета, хотя слогом своим и совершенно отделяется от известных его приемов, но она так явно входит в его драматическую систему и носит на себе так много следов вольной и широкой его кисти, что ее должно почесть сочинением Шекспира» (Пушкин, 1949: 83; курсив источника. - Н. 3.). Особенно впечатляет характеристика, которую Пушкин дает самобытному итальянскому колориту в пьесе: «...в известной мере она (заметка Пушкина. - H. 3.) предвосхищает последующую литературу о couleur local Шекспира, об удивительном знакомстве его с топографией Вероны, итальянским языком и мелкими подробностями итальянского быта...» (Алексеев, 1972: 260). Пушкин пишет: «В ней отразилась Италия, современная поэту, с ее климатом, страстями, праздниками, негой, сонетами, с ее роскошным языком, исполненным блеска и concetti. Так понял Шекспир драматическую местность» (Пушкин, 1949: 83).

Особая симпатия у Пушкина возникает к фигуре Меркуцио: «После Ажюльеты, после Ромео, сих двух очаровательных созданий шекспировской грации, Меркутио, образец молодого кавалера того времени, изысканый, привязчивый, благородный Меркутио есть замечательнейшее лицо изо всей трагедии. Поэт избрал его в представители итальянцев, бывших модным народом Европы, французами XVI века» (там же). М.П. Алексеев объясняет этот интерес Пушкина тем обстоятельством, «что именно вокруг Меркуцио сосредоточено действие в сцене на веронской площади (А. III, сц. 1), которую перевел П. А. Плетнев для “Северных цветов” и для которой заметка Пушкина явилась введением или своего рода комментарием...» (Алексеев, 1972: 260).

Большое значение М. П. Алексеев придал пушкинскому написанию имени Меркуцио: «Пушкин пишет "Меркутио” (как и П. А. Плетнев) в соответствии с орфографией шекспировского оригинала, но, может быть, это свидетельствует и о недостаточном знакомстве русского поэта в то время со всеми особенностями английского произношения; с другой стороны, Пушкин тут же пишет “Ажюльета" в соответствии с шекспировской Juliet, но не с французской Juliette или немецкой Julia; характерно, 
что в сцене, переведенной П. А. Плетневым, героиня именуется Юлией. Отметим, кстати, что до середины 30-х годов английская орфография имени Шекспира в писаниях Пушкина отличалась неустойчивостью: в черновом письме к Н. Н. Раевскому (в конце июля 1825 г.) он писал "Schakespear" и ему же (30 января 1829 г.): "Scheks<peare>" (XIII, 406; XIV, 46); с той же неустойчивостью мы встретимся также и в русской орфографической практике начала 30-х годов» (Алексеев, 1972: 260; см. примеры, приведенные в статье: Алексеев, 1965).

На основании примечания, сопровождавшего публикацию заметки в альманахе («Извлечено из рукописного сочинения А. С. Пушкина»), П. В. Анненков сделал вывод, что эта заметка являлась частью обширного сочинения Пушкина о Шекспиpe, не дошедшего до нас: «Этого рукописного сочинения, однако, нет в бумагах поэта, и мы принуждены ограничиться сбережением только самого отрывка, единственного его остатка...» (Анненков, 1855: 169). Это предположение П. В. Анненкова оспорил М. П. Алексеев, оговариваясь, однако: «П. А. Плетнев писал Пушкину 21 мая 1830 г.: “Хотелось бы мне, чтоб ты ввернул в трактат о Шекспире любимые мои две идеи: 1) Спрашивается, зачем перед публикой позволять действующим лицам говорить неприятности? Отвечается: эти лица и не подозревают о публике: они решительно одни, как любовник с любовницей, как муж с женой, как Меркутио с Бенволио (нецеремонные друзья) <...> 2) Аля чего в одном произведении помещать прозу, полустихи (т. е. стихи без рифм) и настоящие стихи" (Плетнев, 1885: 353). О каком “трактате о Шекспире” идет здесь речь? Может быть, действительно Пушкин предполагал написать статью о Шекспире, для которой успел лишь закончить то, что напечатано Плетневым в “Северных цветах"?» (Алексеев, 1972: 261). П. В. Анненков, отмечая, насколько глубоко Пушкин понимал произведения Шекспира (о чем свидетельствуют, например, черновые варианты писем поэта о «Борисе Годунове»), с сожалением замечает: «...собственно работы над Шекспиром теперь не существует. Блестящим остатком ее могут служить два отрывка: один с разбором Фальстафа, напечатанным посмертным изданием в “Записках Пушкина”, а другой, касающийся драмы Ромео и Юлии и посмертным изданием пропущенный» (Анненков, 1855: 169). Однако М. П. Алексеев отрицал связь между статьей «О "Ромео и Ажюльете" Шекспира» и фрагментом «XVIII» о Шейлоке, Анджело и Фальстафе, относящимся к серии заметок, объединенных заглавием Table-talk, которые были написаны не ранее 1834 г.

М. П. Алексеев справедливо замечает: «Во многих рукописях Пушкина за десятилетие, протекшее между 1826-1836 гг., и печатных статьях того же времени имена Шекспира и героев его произведений упоминаются многократно и по разным поводам» (Алексеев, 1972: 261-262). Исследователь утверждает: «Пушкина, несомненно, интересовали сюжетные аналогии к пьесам Шекспира: об этом свидетельствуют... заметка о "Ромео и Ажульетте" из “Северных цветов" или в его отзыве об Озерове слова: "самые народные траг <едии $>$ Шексп $<$ ира $>$ заимствованы из италия $<$ нских $>$ новелей” (статья “О драме”, 1830; XI, 179)» (там же: 266).

Стихотворение А. С. Пушкина «Что в имени тебе моем?» написано 5 января 1830 г. Это был «ответ на просьбу красавицы польки Каролины Собаньской вписать ей в альбом свое имя. Пушкин познакомился с ней в феврале 1821 г. в Киеве, а позднее встречался в Одессе и в Петербурге. О чувстве поэта к Собаньской свидетельствуют два письма к ней, написанные 2 февраля 1830 г.» (Цявловская, 1959: 718). Аюбопытно, но в первой строке стихотворения можно обнаружить шекспировскую аллюзию. Она 
восходит к известной сцене на балконе - ночному свиданию влюбленных героев в саду после бала у Капулетти в «Ромео и Ажульетте» Шекспира. Именно тогда Ажульетта произносит эти слова:

$J u l$. What's in a name? that which we call a rose

By any other name would smell as sweet...

(II, 2; cм.: Shakespeare, 1827: 240)

В разное время следы влияния этой сцены из «Ромео и Ажульетты», их сходство и различие обнаруживались в сцене свидания у фонтана в «Борисе Годунове» (1825) (см. работы Т. Шоу (Shaw, 1991; 1994; его же в русском переводе: Шоу, 2002), И. Ронен (Ронен, 1997), М. Гринлиф (Greenleaf, 1994) и др.).

Американский пушкинист Т. Шоу высказал предположение, что в сцене «Замок воеводы Мнишка в Самборе» монолог Мнишка, состоящий из 14 стихов, рифмуется, как в сонете. Иначе говоря, является сонетом в драматическом тексте, подобным тем, которые вводил в I и II акты трагедии «Ромео и Ажульетта» Шекспир. Аействительно, Пушкин хорошо знал текст «Ромео и Ажульетты» и даже написал заметку, озаглавленную редакторами «О Ромео и Ажюльете Шекспира» (1830). Как считает Т. Шоу, мысль о сонете как воплощении национального колорита и духа итальянского Возрождения, как и сведения о том, что в «Ромео и Ажульетте» имеются рифмованные сонеты, Пушкин мог почерпнуть из труда Ф. Гизо «Жизнь Шекспира». Взгляды Пушкина на поэтику шекспировской драмы отличаются от взглядов французского критика. Например, пушкинское отношение к Меркуцио было отличным от трактовки Гизо. Пушкин считает его самым ярким героем, тогда как Ги30 почти не говорит о нем. Аалее, Гизо не разграничивает отдельных сонетов в пьесе, его отношение к сонетам было скорее отрицательным (Шоу, 2002: 296-297). То же касается и «Иекций о драматическом искусстве и литературе» А. В. Шлегеля. Шлегель говорил об использовании Шекспиром рифм, которые помогали ему завершить реплики и сцены, делали их более яркими, музыкальными, по форме напоминающими ему английский сонет того времени. Но, по мнению Т. Шоу, Пушкин идет дальше Шлегеля, заметившего рифмы и строфы, похожие на сонет. Пушкин прямо говорит о сонетах в «Ромео и Ажульетте», замечает в пьесе конкретные сонетные формы (там же).

Итак, по мнению Т. Шоу, источником сцены бала в замке воеводы Мнишка является последняя сцена первого акта «Ромео и Ажульетты». Поэт придает ей «местный» (польский) колорит, что в конечном итоге противополагает ее русским сценам. И у Шекспира, и у Пушкина хозяин дома, где происходит бал, - отец героини, мечтающий о счастье дочери, полон ностальгии об ушедшей молодости. Т. Шоу отмечает, что в сценах у Шекспира и Пушкина есть загадка, кем на самом деле является герой: Ромео носит маску, Самозванец скрывает свое истинное имя и положение.

И. Ронен дополняет наблюдения Т. Шоу по поводу шекспировского подтекста сцены «Замок воеводы Мнишка в Самборе»: «Бал у Мнишка с его ярким освещением, музыкой и танцами, учтивой болтовней старика-хозяина, его игривыми воспоминаниями и сожалениями, “Мы, старики, уж нынче не танцуем” (12. 4), приводит на память сцену ужина у старого Капулетти: "For you and I are past our dancing days" (Romeo and Juliet, Act I, Scene 5). Встреча в доме Капулетти ведет к ночному свиданию в саду у Ажульетты, точно так же как свидание в сцене у фонтана следует за танцами у Мнишков» (Ронен, 1997: 58-59). 
Впрочем, объяснение $\Lambda$ жедмитрия в любви к гордой, неуступчивой и расчетливой полячке имеет скорее пародийный, чем драматический характер. У Шекспира Ажульетта призывает Ромео:

Jul. O, swear not by the moon, the inconstant moon,

That monthly changes in her circled orb...

$<\ldots>$

Or, if thou wilt, swear by thy gracious self,

Which is the god of my idolatry,

And I'll believe thee

(II, 2; см.: Shakespeare, 1827: 241).

В переводе Т. А. Щепкиной-Куперник:

О, не клянись луной непостоянной,

Ауной, свой вид меняющей так часто.

Чтоб и твоя любовь не изменилась.

$<\ldots>$

Вовсе не клянись;

Иль, если хочешь, поклянись собою,

Самим собой - души моей кумиром, -

И я поверю

(Шекспир, 1958: 45).

У Пушкина Марина с сарказмом спрашивает Самозванца: «...но чем, нельзя ль узнать, // Клянешься ты?» (Пушкин, 1948: 64).

М. Гринлиф увидела в сцене у фонтана нечто большее, чем простое воссоздание ренессансного колорита на польской почве или пародию на сцену на балконе в «Ромео и Ажульетте» Шекспира. Исследовательница приходит к выводу, что ключевым моментом в понимании этих сцен является не столько их сходство, сколько отличие. По мнению М. Гринлиф, ответ Ромео на вопрос Ажульетты показывает, насколько различны герои этих пьес. Перед нами искренние и еще неопытные любовники, тогда как искушенная Марина и претенциозный Григорий, напротив, умеют вести опасные игры, она заставляет его дрожать, как перед змеей, с которой он ее сравнивает: «И путает, и вьется, и ползет, // Скользит из рук, шипит, грозит и жалит. // Змея! змея! Недаром я дрожал» (там же: 65). В конце сцены у фонтана Марина убеждает Самозванца в необходимости следовать избранной роли, она так объясняет ему перспективу их дальнейших отношений: «Пока тобой не свержен Годунов, // буду слушать я» (там же; см.: Greenleaf, 1994: 198).

М. Гринлиф обнаруживает перекличку сцен у фонтана и в саду Капулетти. Марина, издеваясь, спрашивает Самозванца: «...но чем, нельзя ль узнать, // Клянешься ты? (Пушкин, 1948: 64). Подобным образом Ажульетта обращается к Ромео (мы уже приводили эти слова выше). Но кардинальное отличие этих двух сцен состоит в том, что Ажульетта сразу же признает свою симпатию к Ромео, а Марина же ведет сложную игру: напоминает Аимитрию его ничтожность, провоцирует его на то, чтобы он вернул власть над ней (Greenleaf, 1994: 202).

T. Шоу высказывает предположение, что появление неожиданных рифм у Пушкина свидетельствует о его работе с оригинальным текстом, поскольку французский перевод пьесы Шекспира, выполненный П. Аетурнёром, а затем исправленный Ф. Гизо, «целиком прозаический» (Шоу, 2002: 299). А. М. Аотман выразила сомнение по пово- 
ду этого суждения Т. Шоу. По ее мнению, Пушкин, «работая над "Борисом Годуновым”, еще очень плохо знал английский язык», «читал Шекспира во французском переводе Ф. Гизо» (Иотман, 1996: 321). Мы же считаем, что познания Пушкина в английском языке были достаточными, что подтверждается его постоянным обращением к английскому тексту пьес Шекспира (ср.: Винокур, 1999: 326).

Т. Шоу доказывает, что вслед за приемами создания местного колорита, описанными Ф. Гизо (Шоу, 2002: 297), Пушкин позаимствовал у Шекспира способы рифмовки, что в качестве образца для сцены «Замок воеводы Мнишка в Самборе» он использовал пятую и последнюю сцену первого акта «Ромео и Ажульетты», в частности рифмованный отрывок с «замаскированным» сонетом. Кроме общего сравнения этих двух сцен, исследователь рассматривает структуру рифмованных отрывков сцен из «Бориса Годунова» и «Ромео и Ажульетты».

Сходство изображения Польши у Пушкина с изображением ренессансной Италии Шекспира в популярной в XIX в. опере «Ромео и Юлия», которую Пушкин мог видеть в Одессе, обнаружила И. Ронен. Впрочем, пушкинские герои не отличаются благородством чувств, скорее наоборот: «В отличие от Шекспира, романтический фон и нежные речи любовника в БГ (“Борисе Годунове”. - H. 3.) контрастируют с дальнейшим развитием интриги. Перед Самозванцем не наивная юная возлюбленная. Его встречает блестящая светская авантюристка, готовая отдать свою руку “не юноше, кипящему, безумно / Плененному моею красотой”... а коронованному победителю: “Наконец / Я слышу речь не мальчика, но мужа” (Ронен, 1997: 59). (Подробнее о заимствованиях Пушкина из шекспировских текстов см.: Захаров, 2008: 174-185.)

Была ли начальная строка известного стихотворения Пушкина намеком на отношения знаменитых любовников из пьесы английского драматурга? Вполне возможно. Стихотворение (как и письма к К. Собаньской) и вправду навеяно глубокой печалью, грустью душевных переживаний и щемящим чувством любви.

\section{ЗАКАЮЧЕНИЕ}

Во второй половине XIX - начале XX в. русская культура продолжала развивать пушкинскую модель шекспиризма в творчестве русских писателей (Ф. М. Аостоевский, И. С. Тургенев, А. П. Чехов, А. А. Блок, Б. А. Пастернак и др.). Значительными оказались музыкальные произведения: вдохновленные шекспировской пьесой увертюра-фантазия «Ромео и Ажульетта» П. И. Чайковского и признанный классический балет С. С. Прокофьева. В живописи заметными явлениями стали работы М. А. Врубеля, М. З. Шагала и др. Новаторский характер имели в 1920-1930-х годах театральные постановки пьесы Шекспира режиссеров А.Я. Таирова (1921), С.Э. Радлова (1934) и А. А. Попова (1935).

$\mathrm{K}$ середине XX в. трагедия Шекспира прочно вошла в русскую культуру.

\section{СПИСОК АИТЕРАТУРЫ}

I Академические чтения памяти Владимира Андреевича Аукова, 27 марта 2015 г. : сб. науч. трудов / редкол.: Вал. А. Ауков (отв. ред.) и др. М. : ИзА-во Моск. гуманит. ун-та, 2015. 280 с.

Алексеев, М. П. (1965) К истории написания имени Шекспира в России // Проблемы современной филологии : сб. ст. к семидесятилетию акад. В. В. Виноградова / Акад. наук СССР. Отд-ние литературы и языка ; предисл. Н. Ю. Шведова ; ред. коллегия: чл.-корр. АН СССР М. Б. Храпченко (глав. реА.) и др. М. : Наука. 475 с. С. 304-313.

Алексеев, М. П. (1972) Пушкин и Шекспир // Алексеев, М. П. Пушкин. Сравнительно-исторические исследования. $\Lambda$. : Наука. 468 с. С. 240-280. 
Алексеев, М. П. (1982) Русско-английские литературные связи (XVIII век - первая половина XIX века) М. : Наука. 863 с. (Иитературное наследство. Т. 91).

Алексеев, М. П. (1987) Пушкин и мировая литература / отв. ред. Г. П. Макогоненко, С. А. Фомичев. $\Lambda$. : Наука. 613 с.

Анненков, П. В. (1855) Материалы для биографии Александра Сергеевича Пушкина // Сочинения Пушкина : [в 7 т.]. СПб. : Изд. П. В. Анненкова. Т. 1. IV, 489 с. С. 1-432.

Вацуро, В. Э. (2004) Избранные труды. М. : Языки славянской культуры. 848 с.

Вальберх, И. (1948) Из архива балетмейстера. М. ; А. : Искусство. 191 с.

Вершинин, И. В. (2003) Предромантические тенденции в английской поэзии XVIII века и «поэтизация» культуры : дис. ... А-ра филол. наук. Самара. 407 с.

Винокур, Г. О. (1999) Собрание трудов. М. : Аабиринт ; Брандес. [Т. 3]: Комментарии к «Борису Годунову» А. С. Пушкина. 414 с.

Гайдин, Б. Н. (2009) Вечные образы как константы культуры (интерпретация «гамлетовского вопроса») : дис. ... канд. филос. наук. М. 194 с.

Гозенпуд, А. А. (1959) Музыкальный театр в России. $\Lambda$. : Музгиз. 781 с.

Аамский журнал (1827). М. : Университетская типография. Ч. XVII, № 4.

Аолинин, А. А. (2001) Пушкин и Англия // Всемирное слово. № 14. С. 44-51.

Аолинин, А. А. (2007) Пушкин и Англия : цикл статей. М. : Новое литературное обозрение. $280 \mathrm{c}$.

Елифёрова, М. В. (2003) Шекспировские сюжеты, пересказанные Белкиным // Вопросы литературы. № 1. С. 149-175.

Елифёрова, М. В. (2005) «Не шей ты мне, матушка, красный сарафан...» Комическая семантика женского костюма в «Барышне-крестьянке» // Вопросы литературы. № 4. С. 213-231.

Елифёрова, М. В. (2007) «Повести Белкина» в контексте раннего восприятия Шекспира в России: 1790-1830 : дис. ... канд. филол. наук. М. 267 с.

Есин, С. Н. (2006) Писатель в теории литературы: проблема самоидентификации : дис. ... А-ра филол. наук. М. 467 с.

Заборов, П. Р. (1965) От классицизма к романтизму // Шекспир и русская культура / под ред. М. П. Алексеева. М. ; $\Lambda$. : Наука. 832 с. С. 70-128.

Захаров, Н. В. (2008) Шекспиризм русской классической литературы: тезаурусный анализ / отв. ред. Вл. А. Ауков. М. : Изд-во Моск. гуманит. ун-та. 320 с.

Кузнецова, Т. Ф. (2012) Культурная картина мира: теоретические проблемы. М. : ГИТР. 250 с.

Кузнецова, Т. Ф. (2015) Культурная картина мира как ядро тезауруса в концепции Владимира Андреевича Аукова [Электронный ресурс]// Информационный гуманитарный портал «Знание. Понимание. Умение». № 3 (май — июнь). URL: http://zpu-journal.ru/e-zpu/2015/3/Kuznetsova_Cultural-World-View/ (дата обращения: 20.02.2017).

Кузнецова, Т. Ф., Ауков, Вл. А. (2009) Культурная картина мира в свете тенденций развития культурологии // Вестник Международной академии наук (Русская секция). № 1. С. 66-69.

Купреянова, Е. Н. (1981) А. С. Пушкин // История русской литературы : в 4 т. $\Lambda$. : Наука. T. 2: От сентиментализма к романтизму и реализму. 653 с. С. 235-323.

Аамажаа, Ч. К. (2012) Тезаурусный подход в тувиноведении // Знание. Понимание. Умение. № 2. C. 38-45.

Иевин, Ю. А. (1974) Некоторые вопросы шекспиризма Пушкина // Пушкин. Исследования и материалы. $\Lambda$. : Наука. Т. VII: Пушкин и мировая литература. 276 с. С. 58-85.

Аевин, Ю. А. (1988) Шекспир и русская литература XIX века. $\Lambda$. : Наука. 328 с.

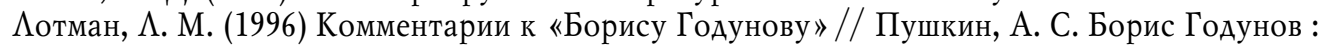
трагедия / предисл., подготов. текста, ст. «Творческая история пьесы» С. А. Фомичева. СПб. : Академический проект. 542 с. С. 129-359.

Ауков, В. А., Ауков Вл. А. (2008) Тезаурусы: Субъектная организация гуманитарного знания. М. : ИзА-во Нац. ин-та бизнеса. 784 с.

Ауков, В. А., Ауков Вл. А. (2013) Тезаурусы II: Тезаурусный подход к пониманию человека и его мира. М. : ИзА-во Нац. ин-та бизнеса. 640 с. 
Ауков, Вл. А. (2006) Предромантизм. М. : Наука. 683 с.

Ауков, Вл. А. (2011) Культ Шекспира и шекспиризация в европейском предромантизме // Шекспировские чтения. 2006 / гл. ред. А. В. Бартошевич ; отв. ред. и сост. вып. И. С. Приходько. М. : Наука. 469 с. С. 182-196.

Иуков, Вл. А., Захаров, Н. В. (2008) Культ Шекспира // Знание. Понимание. Умение. №1. C. $132-141$.

Петрунина, Н. Н. (1987) Проза Пушкина. $\Lambda$. : Наука. 333 с.

Плетнев, П. А. (1885) Сочинения и переписка П. А. Плетнева. СПб. : Тип. Имп. Академии наук. Т. III. XI, 745 с.

Погорский, Э. К. (2012) Картина мира // Знание. Понимание. Умение. № 4. С. 322-323.

Полевой, К. А. (1888) Записки Ксенофонта Алексеевича Полевого. СПб. : А. С. Суворин. [4], VIII, 588 c.

Просцевичус, В. Э. (1998) Пушкин как Шекспир // А. С. Пушкин: филологические и культурологические проблемы изучения : Мат. межд. науч. конф., 28-31 октября 1998 г. Аонецк : АГУ. C. $126-127$.

Пушкин, А. С. (1948) Борис Годунов // Пушкин, А. С. Полное собрание сочинений : в 16 т. М. ; А. : Изд-во АН СССР. Т. 7: Араматические произведения. 395 с. С. 1-98.

Пушкин, А. С. (1949) <О «Ромео и Ажюльете» Шекспира> // Пушкин, А. С. Полное собрание сочинений : в 16 т. М. ; $\Lambda$. : ИзА-во АН СССР. Т. 11: Критика и публицистика, 1819-1834. 600 c. C. 83.

Ронен, И. (1997) Смысловой строй трагедии Пушкина «Борис Годунов». М. : ИЦ-Грант. 160 с.

Северная пчела (1829). 16 февраля. №21. 4 с.

Соломатина, Н. В. (2003) Оскар Уайльд: Создание автомифа и его трансформация в «биографическом жанре» : дис. ... канд. филол. наук. М. 214 с.

Тарасов, А. Б. (2006) Феномен праведничества в художественной картине мира $\Lambda$. Н. Толстого : дис. ... А-ра филол. наук. М. 388 с.

Трыков, В. П. (2016) Биографическая проза Ромена Роллана. «Жизни великих людей», «Пеги». М. : МПГУ. 152 с.

Узин, В. С. (1924) О повестях Белкина. Пг. : Аквилон. 71 с.

Цявловская, Т. Г. (1959) Примечания // Пушкин, А. С. Собрание сочинений: в 10 т. М. : Гослитиздат. Т. 2: Стихотворения 1823-1836. 799 с. С. 659-781.

Шекспир, У. (1772) Монолог Ромео из дейст. V, сц. 3 / пер. М. Сушковой // Вечера. Ч. I, вечер 2-й. С. 14-16.

Шекспир, У. (1958) Ромео и Ажульетта / пер. Т. А. Щепкиной-Куперник // Шекспир, У. Полное собрание сочинений : в 8 т. / под общ. ред. А. А. Смирнова, А. А. Аникста. М. : Искусство. Т. 3.566 с. С. 5-130.

Шоу, Аж. Т. (2002) Поэтика неожиданного у Пушкина. Нерифмованные строки в рифмованной поэзии и рифмованные строки в нерифмованной поэзии / пер. с англ. Т. Скулачевой, М. Гаспарова. М. : Языки славянской культуры. 455 с.

Эйхенбаум, Б. М. (2001) Проблемы поэтики Пушкина // Эйхенбаум, Б. М. «Мой временник» : худож. проза и избр. ст. 20-30-х годов. СПб. : Инапресс. 650, [2] с. С. 543-553.

Greenleaf, M. (1994) Pushkin and Romantic Fashion. Fragment, Elegy, Orient, Irony. Stanford, CA : Stanford University Press. viii, 412 p.

Shakespeare, W. (1827) The Dramatic Works of Shakespeare. London : Printed for R. Thurston [et al.]. xii, [2], $908 \mathrm{p}$.

Shaw, J. T. (1991) Romeo and Juliet, Local Color, and «Mniszek's Sonnet» in Boris Godunov // The Slavic and East European Journal. Vol. 35. No. 1. Spring. P. 1-35.

Shaw, J. T. (1994) Pushkin's Poetics of the Unexpected: The Nonrhymed Lines in the Rhymed Poetry and the Rhymed Lines in the Nonrymed Poetry. Columbus, $\mathrm{OH}$ : Slavica Publishers, Inc. $369 \mathrm{p}$. 
SHAKESPEARE'S «ROMEO AND JULIET»IN A. S. PUSHKIN'S CRITICISM AND POETICS

\section{N. V. ZAKHAROV}

MOSCOW UNIVERSITY FOR THE HUMANITIES

It is believed that W. Shakespeare's tragedy «Romeo and Juliet» did not leave any significant trace in the work of A. S. Pushkin. There can usually be found some similarities in interpreting the love plot, lyrical characters, the conflict between the families etc. The thesaurus approach, developed by V. A. Lukov and Vl. A. Lukov and used by the author of the article to analyze Pushkin's work, is of great importance for Shakespearean studies in Russian literature. The article pays special attention to the role that the sad story of the two loving teenagers played in creative development of the Russian poet.

Starting from the 1770-1780s the Shakespeare-oriented approach began to gain popularity in Russian literature. The magazines of that time start publishing attempts at translations of some small extracts from Shakespeare's plays. The romantic cult of Shakespeare in Russia in the early 19th century was fully preempted by pre-romantic influence of the European literature of the 18th century. Following Shakespeare's example, A. S. Pushkin, V. K. Küchelbecker, A. S Griboedov, O. M. Somov developed a unique national literature containing the spirit of ethnicity. Poet Pushkin was certainly the most important Russian expert on Shakespeare, which can be traced in his creative evolution.

Shakespeare and his characters, Romeo and Juliet in the first place, are constantly mentioned in Pushkin's manuscripts. Their literary and critical level is so significant and unique that some researchers supposed that the poet was going to write a «treatise on Shakespeare». After «Boris Godunov» and «Earl Noolin» Pushkin became more Shakespeare-oriented. References to Shakespeare are quite evident both in poetical works and in his plays.

In the second half of the 19th - early 20th centuries Russian culture continued developing Pushkin's model of Shakespearean approach in works of Russian writers, such as F. M. Dostoevsky, I. S. Turgenev, A. P. Chekhov, A. A. Block, B. L. Pasternak and others. Very important were also musical works, such as inspired by Shakespeare's play overture-fantasy «Romeo and Juliet» by P. I. Tchaikovsky and the recognized classical ballet dance by S. S. Prokofiev. In pictorial art the works by M. A. Vrubel and M. A. Chagall and others gained prominence. Theatre performances of Shakespeare plays were innovative in the 1920-1930s. Thus, by the mid-20th century Shakespearean tragedy gained a firm hold in Russian culture.

Keywords: A. S. Pushkin; W. Shakespeare; «Romeo and Juliet»; literary criticism; literary poetics; thesaurus approach; Shakespearean studies; Russian literature

\section{REFERENCES}

I Akademicheskie chteniia pamiati Vladimira Andreevicha Lukova, 27 marta 2015 g. (2015): collection of scientific papers, Val. A. Lukov et al. (ed.). Moscow, Mosk. gumanit. un-t Publ. 280 p. (In Russ.).

Alekseev, M. P. (1965) K istorii napisaniia imeni Shekspira v Rossii. In: Problemy sovremennoi filologii, sb. st. k semidesiatiletiiu akad. V. V. Vinogradova, Preface by N. Iu. Shvedova; M. B. Khrapchenko et al. (ed.). Moscow, Nauka Publ. 475 p. Pp. 304-313. (In Russ.).

Alekseev, M. P. (1972) Pushkin i Shekspir. In: Alekseev, M. P. Pushkin. Sravnitel'no-istoricheskie issledovaniia. Leningrad, Nauka. 468 p. Pp. 240-280. (In Russ.).

Alekseev, M. P. (1982) Russko-angliiskie literaturnye sviazi (XVIII vek - pervaia polovina $X I X$ veka). Moscow, Nauka. 863 p. (Literaturnoe nasledstvo. Vol. 91). (In Russ.).

Alekseev, M. P. (1987) Pushkin i mirovaia literature, ed. G. P. Makogonenko and S. A. Fomichev. Leningrad, Nauka. 613 p. (In Russ.).

Annenkov, P. V. (1855) Materialy dlia biografii Aleksandra Sergeevicha Pushkina. In: Socbineniia Pushkina: [in 7 vol.]. St. Petersburg, P. V. Annenkov Publ. Vol. 1. IV, 489 p. Pp. 1-432. (In Russ.).

Vatsuro, V. E. (2004) Izbrannye trudy. Moscow, Iazyki slavianskoi kul'tury. 848 p. (In Russ.).

Val'berkh, I. (1948) Iz arkbiva baletmeistera. Moscow, Leningrad, Iskusstvo. 191 p. (In Russ.).

Vershinin, I. V. (2003) Predromanticheskie tendentsii $v$ angliiskoi poezii XVIII veka $i$ "poetizatsiia» kul'tury: Dis. ... Doctor of Philology. Samara. 407 p. (In Russ.). 
Vinokur, G. O. (1999) Sobranie trudov. Moscow, Labirint, Brandes. [Vol. 3]: Kommentarii k «Borisu Godunovu» A. S. Pushkina. 414 p. (In Russ.).

Gaidin, B. N. (2009) Vechnye obrazy kak konstanty kul'tury (interpretatsiia "gamletovskogo voprosa») : Dis. ... Candidate oh Philosophy. Moscow. 194 p. (In Russ.).

Gozenpud, A. A. (1959) Muzykal'nyi teatr v Rossii. Leningrad, Muzgiz. 781 p. (In Russ.).

Damskii zhurnal (1827). Moscow, Universitetskaia tipografiia. Vol. XVII, no. 4. (In Russ.).

Dolinin, A. A. (2001) Pushkin i Angliia. Vsemirnoe slovo, no. 14, pp. 44-51. (In Russ.).

Dolinin, A. A. (2007) Pusbkin i Angliia. Moscow, Novoe literaturnoe obozrenie. 280 p. (In Russ.).

Eliferova, M. V. (2003) Shekspirovskie siuzhety, pereskazannye Belkinym. Voprosy literatury, no. 1, pp. 149-175. (In Russ.).

Eliferova, M. V. (2005) «Ne shei ty mne, matushka, krasnyi sarafan...». Komicheskaia semantika zhenskogo kostiuma v «Baryshne-krest'ianke». Voprosy literatury, no. 4, pp. 213-231. (In Russ.).

Eliferova, M. V. (2007) "Povesti Belkina» v kontekste rannego vospriiatiia Shekspira v Rossii: 1790-1830 : Dis. ... Candidate of Philology. Moscow. 267 p. (In Russ.).

Esin, S. N. (2006) Pisatel' v teorii literatury: problema samoidentifikatsii: Dis.... Doctor of Philology. Moscow. 467 p. (In Russ.).

Zaborov, P. R. (1965) Ot klassitsizma k romantizmu. In: Shekspir i russkaia kul'tura, ed. M. P. Alekseeva. Moscow, Leningrad, Nauka. 832 p. Pp. 70-128. (In Russ.).

Zakharov, N. V. (2008) Shekspirizm russkoi klassicheskoi literatury: tezaurusnyi analiz, ed. Vl. A. Lukov. Moscow, Mosk. gumanit. un-t Publ. 320 p. (In Russ.).

Kuznetsova, T. F. (2012) Kul'turnaia kartina mira: teoreticheskie problemy. Moscow, GITR. 250 p. (In Russ.).

Kuznetsova, T. F. (2015) Kul'turnaia kartina mira kak iadro tezaurusa v kontseptsii Vladimira Andreevicha Lukova. Informatsionnyi gumanitarnyi portal «Znanie. Ponimanie. Umenie», no. 3 (May - June) [online] Available at: http://zpu-journal.ru/e-zpu/2015/3/Kuznetsova_CulturalWorld-View/ (access date: 20.02.2017). (In Russ.).

Kuznetsova, T. F., Lukov, Vl. A. (2009) Kul'turnaia kartina mira v svete tendentsii razvitiia kul'turologii. Vestnik Mezhdunarodnoi akademii nauk (Russkaia sektsiia), no. 1, pp. 66-69. (In Russ.).

Kupreianova, E. N. (1981) A. S. Pushkin. In: Istoriia russkoi literatury : in 4 vol. Leningrad, Nauka. Vol. 2: Ot sentimentalizma k romantizmu i realizmu. 653 p. Pp. 235-323. (In Russ.).

Lamazhaa, Ch. K. (2012) Tezaurusnyi podkhod v tuvinovedenii. Znanie. Ponimanie. Umenie, no. 2, pp. 38-45. (In Russ.).

Levin, Iu. D. (1974) Nekotorye voprosy shekspirizma Pushkina. In: Pushkin. Issledovaniia i materialy. Leningrad, Nauka. Vol. VII: Pushkin i mirovaia literatura. 276 p. Pp. 58-85. (In Russ.).

Levin, Iu. D. (1988) Shekspir i russkaia literatura XIX veka. Leningrad, Nauka. 328 p. (In Russ.).

Lotman, L. M. (1996) Kommentarii k «Borisu Godunovu». In: Pushkin, A. S. Boris Godunov : tragediia, predisl., podgotov. teksta, st. «Tvorcheskaia istoriia p'esy» S. A. Fomicheva. St. Petersburg, Akademicheskii proekt. 542 p. Pp. 129-359. (In Russ.).

Lukov, V. A. and Lukov Vl. A. (2008) Tezaurusy: Sub' ektnaia organizatsiia gumanitarnogo znaniia. Moscow, Nats. in-t biznesa Publ. 784 p. (In Russ.).

Lukov, V. A. and Lukov Vl. A. (2013) Tezaurusy II: Tezaurusnyi podkhod k ponimaniiu cheloveka i ego mira. Moscow, Nats. in-t biznesa Publ. 640 p. (In Russ.).

Lukov, Vl. A. (2006) Predromantizm. Moscow, Nauka. 683 p. (In Russ.).

Lukov, Vl. A. (2011) Kul't Shekspira i shekspirizatsiia v evropeiskom predromantizme. In: Shekspirovskie chteniia. 2006, ed. A. V. Bartoshevich, I. S. Prikhod'ko. Moscow, Nauka. 469 p. Pp. 182-196. (In Russ.).

Lukov, Vl. A. and Zakharov, N. V. (2008) Kul't Shekspira. Znanie. Ponimanie. Umenie, no. 1, pp. 132-141. (In Russ.).

Petrunina, N. N. (1987) Proza Pusbkina. Leningrad, Nauka. 333 p. (In Russ.).

Pletnev, P. A. (1885) Sochineniia i perepiska P. A. Pletneva. St. Petersburg, Tip. Imp. Akademii nauk. Vol. III. XI, 745, [1] p. (In Russ.). 
Pogorskii, E. K. (2012) Kartina mira. Znanie. Ponimanie. Umenie, no. 4, pp. 322-323. (In Russ.).

Polevoi, K. A. (1888) Zapiski Ksenofonta Alekseevicha Polevogo. St. Petersburg, A. S. Suvorin. [4], VIII, 588 p. (In Russ.).

Prostsevichus, V. E. (1998) Pushkin kak Shekspir. In: A. S. Pushkin: filologicheskie i kul'turologicheskie problemy izucheniia : Mat. mezhd. nauch. konf., 28-31 oktiabria 1998 g. Donetsk, DGU. Pp. 126-127. (In Russ.).

Pushkin, A. S. (1948) Boris Godunov. In: Pushkin A. S. Polnoe sobranie socbinenii : in 16 vol. Moscow, Leninrgad, AN SSSR Publ. Vol. 7: Dramaticheskie proizvedeniia. 395 p. Pp. 1-98. (In Russ.).

Pushkin, A. S. (1949) <0 «Romeo i Dzhiul'ete» Shekspira>. Pushkin, A. S. Polnoe sobranie sochinenii : in 16 vol. Moscow, Leninrgad, AN SSSR Publ. Vol. 11: Kritika i publitsistika, 1819-1834. 600 p. P. 83. (In Russ.).

Ronen, I. (1997) Smyslovoi stroi tragedii Pushkina «Boris Godunov». Moscow, ITs-Grant. 160 p. (In Russ.).

Severnaia pchela (1829). 16 February, no. 21.4 p. (In Russ.).

Solomatina, N. V. (2003) Oskar Uail'd: Sozdanie avtomifa $i$ ego transformatsiia $v$ «biograficheskom zhanre» : Dis. ... Candidate of Philology. Moscow. 214 p. (In Russ.).

Tarasov, A. B. (2006) Fenomen pravednichestva $v$ kbudozhestvennoi kartine mira L. N. Tolstogo: Dis. ... Doctor of Philology. Moscow. 388 p. (In Russ.).

Trykov, V. P. (2016) Biograficheskaia proza Romena Rollana. "Zhizni velikikb liudei», "Pegi». Moscow, MPGU. 152 p. (In Russ.).

Uzin, V. S. (1924) O povestiakb Belkina. Pg., Akvilon. 71 p. (In Russ.).

Tsiavlovskaia, T. G. (1959) Primechaniia. In: Pushkin, A. S. Sobranie socbinenii: in 10 vol. Moscow, Goslitizdat. Vol. 2: Stikhotvoreniia 1823-1836. 799 p. Pp. 659-781. (In Russ.).

Shekspir, U. (1772) Monolog Romeo iz deist. V, sts. 3, transl. by M. Sushkova. Vechera, vol. I, vecher 2-i. Pp. 14-16. (In Russ.).

Shekspir, U. (1958) Romeo i Dzhul'etta, transl. by T. L. Shchepkina-Kupernik. In: Shekspir, U. Polnoe sobranie socbinenii : in 8 vol., ed. A. A. Smirnov and A. A. Anikst. Moscow, Iskusstvo. Vol. 3. 566 p. Pp. 5-130. (In Russ.).

Shou, Dzh. T. (2002) Poetika neozbidannogo u Pushkina. Nerifmovannye stroki $v$ rifmovannoi poezii $i$ rifmovannye stroki $v$ nerifmovannoi poezii, transl. by T. Skulacheva and M. Gasparov. Moscow, Iazyki slavianskoi kul'tury. 455 p. (In Russ.).

Eikhenbaum, B. M. (2001) Problemy poetiki Pushkina. In: Eikhenbaum, B. M. «Moi vremennik» : kbudozh. proza i izbr. st. 20-30-kh godov. St. Petersburg, Inapress. 650 p. Pp. 543-553. (In Russ.).

Greenleaf, M. (1994) Pushkin and Romantic Fasbion. Fragment, Elegy, Orient, Irony. Stanford, CA, Stanford University Press. viii, 412 p.

Shakespeare, W. (1827) The Dramatic Works of Shakespeare. London, Printed for R. Thurston [et al.]. xii, [2], $908 \mathrm{p}$.

Shaw, J. T. (1991) Romeo and Juliet, Local Color, and «Mniszek's Sonnet» in Boris Godunov. The Slavic and East European Journal, vol. 35, no. 1. Spring, pp. 1-35.

Shaw, J. T. (1994) Pushkin's Poetics of the Unexpected: The Nonrbymed Lines in the Rbymed Poetry and the Rbymed Lines in the Nonrymed Poetry. Columbus, OH, Slavica Publishers, Inc. $369 \mathrm{p}$.

Submission date: 28.02.2017.

Захаров Николай Владимирович - доктор философии (PhD), кандидат филологических наук, директор Центра теории и истории культуры Института фундаментальных и прикладных исследований Московского гуманитарного университета, ученый секретарь Шекспировской комиссии РАН, академик Международной академии наук (IAS). Адрес: 111395, Россия, г. Москва, ул. Юности, А. 5, корп. 6. Тел.: +7 (499) 374-75-95. Эл. адрес: nikoltine@yandex.ru 
Zakharov Nikolay Vladimirovich, Doctor of Philosophy, Candidate of Philology, Director, Centre of Theory and History of Culture, Institute of Fundamental and Applied Studies, Moscow University for the Humanities; Full Member, International Academy of Sciences; Academic Secretary, Shakespeare Committee, Russian Academy of Sciences. Postal address: 5 Bldg. 6, Yunosti St., Moscow, Russian Federation 111395. Tel.: +7 (499) 374-75-95. E-mail: nikoltine@yandex.ru 